\title{
LIQUIDITY MANAGEMENT REQUIREMENT AND FINANCIAL PERFORMANCE OF COMMERCIAL BANKS IN RWANDA: A CASE OF BANK OF KIGALI
}

\author{
*Buhangu Safi ${ }^{1 *}$, Paul Munene Muiruri ${ }^{2}$, Safari Ernest ${ }^{3}$ \\ ${ }^{* l}$ MBA, Finance Option, School of business and Economics Mount Kenya University, Rwanda \\ ${ }^{2} \mathrm{Dr}$, Lecturer, Mount Kenya University, School of business and Economics, Rwanda \\ ${ }^{3} \mathrm{Dr}$, Lecturer, Mount Kenya University, School of Hospitality and Tourism, Rwanda $\backslash$
}

*Corresponding Author: -

\begin{abstract}
: -
liquidity demands from depositors and borrowers of credit are not too correlated, an intermediary reduces its cash buffer by serving both customers. The study looked at effects of liquidity management requirement on commercial banks' financial performance in Rwanda a case of the bank of Kigali. The study specifically focused on: effect of credit risk, capital requirement, as well as liquidity requirement on banks' financial performance in Rwanda from 2016 to 2020. This research will help the learner get her master's degree in finance as it is the requirement to get this degree; not only this but also by going through the literature review, the empirical review, and all steps of the research process, the researcher research skills will be high and empowered for the future field research. The study also provided different recommendations of the strategies that will be necessary and essential to be implemented in banks to achieve their financial performance. The 110 sizes were chosen through systematic random sampling and stratified sampling method from the population, and the data was gathered from respondents through questionnaires; documentary analysis was also used. Data were tabulated, coded, analyzed, and interpreted using SPSS (Version 22.0). The research revealed that at bank of Kigali, use of prudential loan management strategies has a significant positive association with the performance of a bank of Kigali as it is being indicated by the views of liquidity management requirement relates positively with financial performance of bank of Kigali and the relationship is significant since $(\beta=0.225, p<0.5 ; p=0.000)$. from multiple regression analysis. The research concluded that loan management strategies greatly influences financial performance as justified by the high mean and homogeneity standard deviation of the variables and positive P-Values obtained from multiple regression analysis.
\end{abstract}

Keywords: - liquidity management strategies; Financial Performance: Commercial Banks

\section{(a) $(\$)$}




\subsection{INTRODUCTION}

Bank prudential regulations are rule which subject the commercial banks to definite standards, restrictions and guidelines. This prudential regulatory crafts transparency between banks and the firms with whom they do business with, among other factors. Prudential regulations target at guaranteeing the safe and sound functioning of commercial banks, set by governments through regulatory agencies. Proponents' prudential regulation often pivot their arguments on the 'too huge to fail' concept (Muiruri,2015)

Liquidity is merely easiness with which commercial banks' resources is uncashed in period of essential or their truthful worth. it's that worth of an investment, that aids an ad bank to retort to any money state of affairs necessitating the exigent potion of cash. Liquidity is needed to encounter the bank's unvarying money responsibilities, particularly while not dropping into its reserves (Pandlev, 2010)

Strahan (2008) cited that Kashyap et al., (2002) argued that as long as liquidity demands from depositors and borrowers of credit are not too correlated, an intermediary reduces its cash buffer by serving both customers. Holding cash raises costs for both agency and tax reasons. Thus, their model yielded a diversification synergy between transactions deposits and unused loan commitment. Banks embrace nice liquidity, they are doing thus at the chance value of some asset which might give rise to great earnings (Tang,2003).. The exchange that largely exist between profit as well as solvency risk are established by discerning that a change from temporary securities to lasting equities or debt increases a bank's recovery and upsurges its solvency hazards, and the converse is true. Thus a great solvency ratio directs less perilous as well as less productive banks (Paul2015).

Solvency shows the potential of the bank to satisfy its economic duties in an apt as well as operational manner. There are differences among researcher concerning the solvency ratios. the foremost shared financial ratios that replicate the solvency situation of a bank, in line with Samad (2014), square measure client deposit to total bank resources and total loan to client deposits. Many researchers use the various ratios to asses solvency level. for example, Ilhomovich (2009) study the use the money to deposit equilibrium on extent banks' solvency level in

Asian country. The precarious call to bank directors take denotes on solvency as well as expressly to the metric of their needs connected to deposits and loans. The importance of solvency can be removed from each bank, as a solvency deficit at a selected bank will have general consequences (CBK, 2019). it's repelled that once banks have high solvency ratio, this happen because the chance of value of some quality, that may yield high profits (Kamau, 2009).

The CBK wants establishments to uphold lowest money balances as a buffer beside their savers and alternative obligations. Presently, the solvency ratio is ten percent. These needs square measure of lawfully, voluntary, besides therefore the National bank fully inflict penalties on at all organization, that flops to uphold the minimum reserve. The commercial institution Kenya appearance terribly modest, in decision making by the quantity of native and international banks within the business (CBK, 2019). Nevertheless, Fuchus \& Beck (2004) pointed out that the majority clients in Kenya face easy time in to get financial service in country.

Diamond and Dybvig (2013) said that the fluid bank account open through a cash moderator develops family units protections against liquidity chance and advances utilization smoothing. In their demonstrate, a bank is additionally a component to permit financial specialists to back illiquid with tall return comes. This show does not recommend a genuine interaction between transfer and keeping. cutting edge considers have provoke coalescing human movement to liquidity hazard in each deposit-taking and transfer yields a risk-reducing characteristic action. Odunga et al., (2013) watched the affected of liquidity and capital ampleness on the operational effectiveness of forty mechanical banks in arrive for the number 2005-2011. They build up that a bank's execution is settled by but an advert bank moves forward to structure its operational approaches. They a part of that mechanical banks with satisfactory resources slant to allurement loads of certainty with clients since of the potential to talk short-term cash commitments. it is so essential for and gain. Kamau (2009) contended that once industrial banks hold high liquidity, they're doing therefore at the prospect worth of some and, producing high returns.

At the national level, the report of bank supervision of 1995-2007 in Rwanda indicated that economic conditions, deficient practices in granting and managing loans, and complex terms of collateral are some of the explanations for the extraordinary level of prudential loans in the banking sector (NBR,2018). It is upon this background; this study aims at examining the effects of prudential loan management towards the monetary excellence of financial institutions in Rwanda

\subsection{Objectives of the Study}

To determine effect liquidity management requirement on the financial performance of the bank of Kigali in Rwanda

\subsection{Research Hypotheses}

H01: There is no significant relationship between liquidity management requirement and the financial performance of the bank of Kigali in Rwanda

\subsection{Review of Literature}

2.1 Theoretical Literature

Kamau (2009) same that after mechanical banks grasp decent liquidity, they're doing subsequently at the prospect worth of a few wander, making extraordinary profit. Kamau development that trade of happen between returns 
and dissolvability dangers that unit of measurement familiar with by a move from transitory value to enduring ones. This move in securities propels a bank's recuperation, in this way amassed its liquidity dangers, and conjointly the reverse is genuine. Current considers recommend that combining revelation to dissolvability hazard in each depositer and credit clients to produces a risk-reducing agreeable effort. Loutskina and Strahan (2018)) fought that as long as liquidity strains from depositors and borrowers of credit don't show up to be as well associated, relate middle reduces its cash guard by serving each clients. Holding cash can increment costs on office and charge reasons. Hence, their hypothesis made a variety agreeable exertion between dealings stores and undeveloped advance commitment..

Diamond and Dybvig (2013) said that the fluid bank account open through a cash moderator develops family units protections against liquidity chance and advances utilization smoothing. In their demonstrate, a bank is additionally a component to permit financial specialists to back illiquid with tall return comes. This show does not recommend a genuine interaction between transfer and keeping. cutting edge considers have provoke coalescing human movement to liquidity hazard in each deposit-taking and transfer yields a risk-reducing characteristic action. Odunga et al., (2013) watched the affected of liquidity and capital ampleness on the operational effectiveness of forty mechanical banks in arrive for the number 2005-2011. They build up that a bank's execution is settled by but an advert bank moves forward to structure its operational approaches. They a part of that mechanical banks with satisfactory resources slant to allurement loads of certainty with clients since of the potential to talk short-term cash commitments. it is so essential for and gain. Kamau (2009) contended that once industrial banks hold high liquidity, they're doing therefore at the prospect worth of some and, producing high returns.

\subsection{Empirical literature}

The researcher is interested in examining the effects of liquidity management requirement on the financial performance of banks. no study among them examined the effects of liquidity management requirement on account of banks financially. In addition to this, most of them were carried out in Europe and Asian countries, a few of them were in Kenya, and only one research by Mwine (2018) was carried out in Rwanda. Just to mention a few reasons why, this time, the researcher examines the effects of prudential loan management strategies and banks' financial performance in Rwanda, hence Author needs to verify the hypothesis with the case study of the bank of Kigali. Thus, this current study is later done to bridge this gap.

Fredrick (2012) has observed the effect of credit risk management on banks' performance in Republic of Kenya. The study has used the even-toed ungulate model as a proxy for credit risk supervision. Claudine \& Felix (2011) examined the connection between bank performance as well as credit risk. It can be established from their results that ROE as well as ROA each measure revenue, were linked to the ratio of bad loans to total loans of firms, thus leading to a waning in profit.

Mwine (2018) study establish that the discrepancies affected by non-performing loans to performance, either ROE or ROA, is not statistically significant; this may be instigated by the capital structure and regaining policies of banks. This gives the reassurance of saying that commercial banks' operations in Rwanda were improved since the culture of loan repayment is understood and retained by the customers.

Ho, et al., (2019) studied on loan administration strategies of some banks in Malaysia revealed that many banks failed due to some clients who are able the given loan about the exchange, loaning, payment, and other banks. Credit risk seems from a bank's trade, economic, and business establishments.

In the study carried out by $\mathrm{Hu}$ et al., (2016) using multi-regression analysis, he assessed the link between possession construction in banks of Taiwan and APIs. This study found out that bank scope impacts badly to NPLs through variation would not be a factor; the study found that nations with many private banks have many performing loans. The study put forward by Epure and LA Fuente (2012) in Spain revealed that inadequate investment capital and absence of managerial participation in operations bring about unpredicted revenues in the financial organization and further main to more risks linked loss. management.

Paul,(2015) studied the effects of central bank regulatory requirements on financial performance of commercial banks in Kenya. The study employed descriptive research design. Primary data was collected from 172 key bank officials who were randomly sampled and data were collected by use of a questionnaire. Secondary data was collected from most recent published annual financial statements and banks supervision records at the Central Bank of Kenya, from 2009 to 2013 . The study found that liquidity requirement positively contributed to financial performance of commercial banks in Kenya.

\subsection{Theoretical framework}

The theoretical review helps determine the theories related to the prudential loan management strategies and how they are related to the banks' evaluation financially.

2.3.1 Liquidity Preference Theory

The third theory that guided the study was liquidity preference theory proposed by United Kingdom economist John Maynard Keynes. Keynes observed that all factors held constant, people prefer to hold cash (liquidity) rather than any other form of assets and they will demand a premium for investing in illiquid assets such as bonds, stocks and real estates (Bibow, 1995). The analogy of Keynes theory is imperative on the assets and liabilities functions of a commercial bank. The theory explains why banks will undertake to compensate for liabilities and provides essence of why banks will seek compensation for their assets. Therefore, banks will charge higher interest rates 
where possibility of default is higher hence liquidity preference theory

\subsection{Methodology}

\subsection{Research Design}

The research approaches were quantitative and qualitative. The study adopted descriptive research design is valid since it helped collect data of the current situation of loan management strategies to see the link of loan management strategies on the financial performance of banks, the case of the bank of Kigali.

\subsection{Target Population}

e target population of this study are75 loan officers and 75 recovery officers in Kigali city bank of Kigali branches providing this study with a target population of 150 (Bank of Kigali, 2021).

\subsection{Sample Design}

research used the formula of Yamane. during this vein, the exactitude error is five-hitter, and also the confidential interval is ninety fifth, whereas the entire population size is indicated by $\mathrm{N}$ and also the sample size by $\mathrm{n}$. The formula was expressed as follows

$$
\mathrm{n}=\frac{\mathrm{N}}{1+\mathrm{N}(\mathrm{e}) 2}=\frac{150}{1+150(0.05)^{2}}=110
$$

It is on this crushed that the researcher designated 55 loan officers and 55 recovery officers. The population that counted are those that are going to give the desired information.

Table:3.1 Population under Study and Sample Size

\begin{tabular}{cccc}
\hline Level of management & Target Population & Proportion & Sample Size \\
\hline Loan officers & 75 & 50 & 55 \\
Recovery officers & 75 & 50 & 55 \\
Total & 150 & 100 & 110 \\
\hline
\end{tabular}

Source: Researcher (2021)

\subsection{Data collection methods}

Primary data in this research was collected from loan and recovery officers. Secondary data for this study were the books and other documents such as reports, memoirs all related to the research field. This technique helped analyze the documents which contain the financial performance of banks from 2016 to 2020 in a bank of Kigali.

The researcher used a questionnaire with a mixed bag of cross-ended questions and open-ended questions to collect data from the respondents related to prudential loan management strategies and financial performance of commercial banks in Rwanda, particularly the bank of Kigali. An authorization letter from Mount Kenya University was given to administer to the research bank of Kigali. A pilot study was conducted on 15 people who are not involved in the research to ensure reliability. After Cronbach's Alpha Coefficient was computerized in SPSS version 23.0 to determine how items correlate to one another, according to Amin (2015), the Coefficient must be 0.7 and above to certify that the instrument is reliable.

\subsection{Data Analysis}

The data were entered in SPSS software version 22.0 and descriptive statistic means, and standard deviations were used while inferential statistic panel regression and correlation analysis was used. To analyze the relationships between the dependent variable and independent variables, a conceptual framework and the Ordinary Least Squares (OLS) was utilized to establish a relationship among the three independent parameters and dependent parameters (financial performance of banks in Rwanda). The magnitude of the Variable was measured at the confidence level of $95 \%$. The general Panel models that were specified and tested was given the following equations:

$$
\mathrm{Y} 1=\beta 0+\beta 1 \mathrm{X} 1+\varepsilon \mathrm{Y} 2=\beta 0+\beta 2 \mathrm{X} 1+\varepsilon
$$

Where;

$\mathrm{Y} 1=($ financial performance of banks proxy by ROA) $\mathrm{Y} 2=($ financial performance of banks proxy by ROE $) \beta 0=$ intercept

$\beta=$ Coefficient of independent parameters

$\mathrm{X} 1$ - liquidity management

$\varepsilon=$ Error Term

\subsection{Research Findings And Discussion}

\subsection{Demographic characteristics of participants}

The population targeted in this research was made up of loan and recovery officers of the bank of Kigali. Subsections below detailed the demographic characteristics: In the current study, the accessible population (sample) was made up of both men and women. In table three, the researcher highlights their statistics. The following table presents the statistics of both of them. 


\section{Gender of respondents}

\begin{tabular}{|c|c|c|c|}
\hline Gender & & & Percent \\
\hline Male & 50 & 45.5 & \\
\hline Female & 60 & 54.5 & \\
\hline Total & 110 & 100.0 & \\
\hline
\end{tabular}

Source: primary data (2021)

As the results reveal in table $4.1,54.5 \%$ of respondents were female while $45.5 \%$ were males. This implies that there is a gender balance in the sample selected from the bank of Kigali. Albeit the gender balance reigns at the bank mentioned above, the large number was female, as the results indicated.

Classification of respondents by age groups

In this research study, the researcher considered the distribution of informants according to their age. Table 4.2 gives us the details of the age group of respondents.

\section{Age group of respondents}

\begin{tabular}{ccc}
\hline Age group of respondents & Frequency & Percent \\
\hline $20-30$ & 12 & 10.9 \\
$31-40$ & 60 & 54.5 \\
$41-50$ & 30 & 27.3 \\
$51-60$ & 8 & 7.3 \\
Total & 110 & 100.0 \\
\hline
\end{tabular}

Source: primary data(2021)

The table 4.2 shows that at bank of Kigali there are different categories of age bracket. A large number of employee- respondents (54.5\%) range between $31-40$ years old, while $27.3 \%$ of respondents are ranged between 41-50 years old. This age aspect implies that at bank of Kigali, a great number of employees seem young.

\subsubsection{Classification of respondents by experience}

The table 4.3 indicates the working experience of respondents sampled at bank of Kigali

Table:4.1Experience of respondents

\begin{tabular}{llcc}
\hline Experience & & Frequency & Percent \\
\hline $0-2$ Years & 20 & 18.2 & 27.3 \\
2 -4 Years & 30 & 54.5 \\
4 years and above & 60 & 100.0 & \\
Total & 110 & &
\end{tabular}

Source: primary data (2021)

Table 4.3 indicates that at the Kigali bank, there are different levels of working experience among the respondents. The results reveal that $81.8 \%$ of them have two to more than four years of working experience while only $18.2 \%$ have less than two years of working experience.

In table 4.4, the researcher showed participants according to their degrees.

Table:4.2 Educational level of respondents

\begin{tabular}{|c|c|c|c|}
\hline Education level & & & Percent \\
\hline $\begin{array}{c}\text { post graduate } \\
\text { Bachelor degree }\end{array}$ & $\begin{array}{l}20 \\
80\end{array}$ & $\begin{array}{l}18.2 \\
72.7\end{array}$ & \\
\hline Diploma & 10 & 9.1 & \\
\hline Total & 110 & 100.0 & \\
\hline
\end{tabular}

Source: primary data (2021)

As table 4.4 indicates that at the bank of Kigali, the highest percentage of employee respondents were educated at Bachelor degree education level with the rate of $72.7 \%$, and $18.2 \%$ with post-graduate while few of them, $9.1 \%$ have Diploma. This implies that as long as a Bachelor's degree is among the highest education levels, these employees have the skills and academic knowledge to get the work performed well. Such respondents provided reliable information on the topic under study. So, the respondents' educational level is generally reflected as vital 
since it is a factor of working excellence of the workers, which can improve the bank of Kigali loan management strategies which lead to its performance. It is also revealed that the information collected was given by that are skillful on the topic under the study.

\subsection{Presentation of Findings}

variable under prudential loan management strategies in this study was liquidity requirement. The researcher was interested in knowing the status of liquidity requirements in sampled banks of Kigali branches and their impact on financial performance. To gather information on this variable, the researcher asked questions to the key informant, and their answers are below:

\begin{tabular}{|c|c|c|c|c|c|c|c|c|}
\hline statement & $\mathrm{N}$ & SD & $\mathrm{D}$ & $\mathrm{N}$ & A & SA & $\mathrm{X}$ & Std. D \\
\hline \multirow{2}{*}{$\begin{array}{l}\text { Liquidity management affects financial performance of our } \\
\text { bank }\end{array}$} & & $\mathrm{F}(\%)$ & $\mathrm{F}(\%)$ & $\mathrm{F}(\%)$ & $\mathrm{F}(\%)$ & $\mathrm{F}(\%)$ & & \\
\hline & 110 & $11(10.0)$ & $8(7.3)$ & $0(0.0)$ & $49(44.5)$ & $42(38.1)^{3}$ & 3.98 & .92 \\
\hline \multirow[t]{2}{*}{$\begin{array}{l}\text { Formulation of liquidity policies have been a challenge in } \\
\text { performance of this bank }\end{array}$} & & $9(8.2)$ & $7(6.4)$ & $7(6.4)$ & $57(51.8)$ & $30(27.3)$ & & \\
\hline & 110 & & & & & & \multicolumn{2}{|c|}{3.831 .14} \\
\hline $\begin{array}{l}\text { Client deposit tom total asset and customer deposit measure } \\
\text { our bank liquidity }\end{array}$ & 110 & $7(6.4)$ & $9(8.2)$ & $5(4.5)$ & $60(54.5)$ & $29(26.4)$ & \multicolumn{2}{|c|}{3.861 .09} \\
\hline \multirow[t]{2}{*}{$\begin{array}{l}\text { It is important for NBR to ensure full compliance with } \\
\text { minimum liquidity requirement }\end{array}$} & & $11(10.0)$ & $8(7.3)$ & $5(4.5)$ & $49(44.5)$ & $37(33.6)$ & & \\
\hline & 110 & & & & & & \multicolumn{2}{|c|}{3.841 .25} \\
\hline $\begin{array}{l}\text { Consistent appraisals have been done on gathering Rules to } \\
\text { advance state of liquidity of this bank }\end{array}$ & & $10(9.1)$ & $8(7.3)$ & $5(4.5)$ & \multicolumn{4}{|c|}{$50(45.5) 37(33.6)$} \\
\hline
\end{tabular}

A severe rule is more real in loanretrieval

$11010(9.1) \quad 11(10.0) 3(2.7) \quad 48(43.6) 38(34.5) 3.841 .25$

Profitindictedupsetloan payment than a mercifulrule

$1109(8.2) \quad 14(12.7) 14(12.7) 35(31.8) 38(34.5) 3.711 .28$

Source: primary data (2021)

Legend: N: Number of respondents, SD: Strongly Disagree, D: Disagree, N: Neutral, A: Agree, SA: Strongly Agree, X: Mean, St. D: Standard Deviation, SD $\leq 1$ : Homogeneity SD, SD $>1$ : Heterogeneity SD

Many participants agreed on the sampled bank of Kigali branches that Liquidity management affects financial performance of our bank by a high mean of 3.98 and homogeneous perception as the standard deviation was 0.92 . These findings indicated that Formulation of liquidity policies have been a challenge in performance of this bank on high Mean of 3.83 and heterogeneity in responses as indicated by the standard deviation of 1.14. Furthermore, many of the respondents agreed about the item that sampled bank of Kigali Client deposit tom total asset and customer deposit measure our bank liquidity, showed by high mean of 3.86 and standard deviation 1.09. This implies that recovery and loan officers respect the enforcement of guarantee policies in case of loan defaults; this helps repay the loan defaulted and then leads to the bank's financial performance.

In examining whether in the sampled bank of Kigali A severe rule is more real in loan retrievals, the findings in Table 4.7 indicated a mean of 3.84, which is a high mean, which means that many agree with the item and heterogeneity in responses as shown by the standard deviation of 1.25 which is more significant than one (SD $>1$ ). Regarding the Profit indicted upset loan payment than prudential rule, statistics in Table 4.7indicated a high mean of 3.87 and 3.84, respectively. These findings suggested that the more than $70 \%$ of respondents confirmed that liquidity requirement was used as the critical measure of prudential loan management to ensure banks' financial performance. 


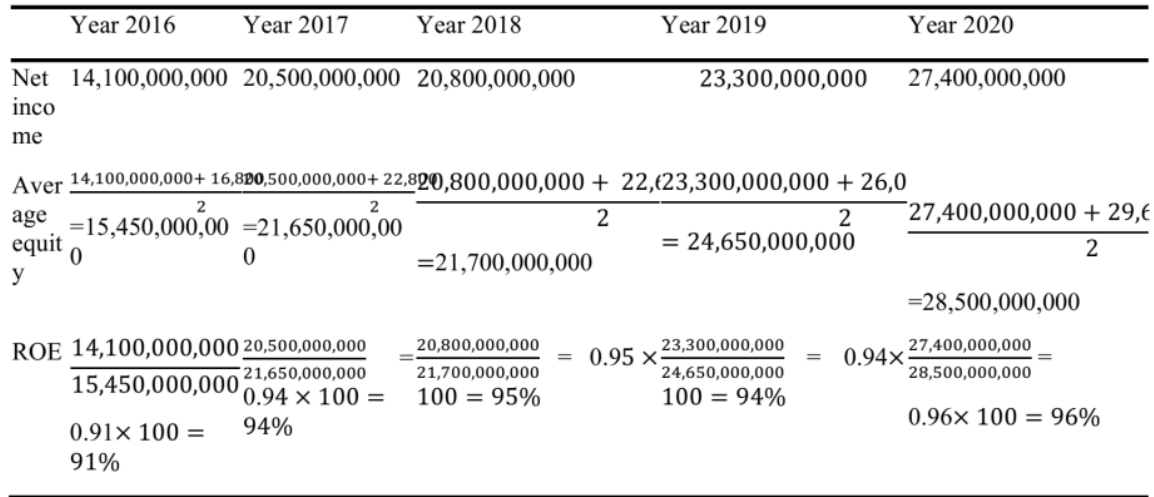

Table:4.3 Overall loan management strategies of bank of Kigali

\begin{tabular}{|c|c|c|c|c|c|}
\hline Loan management strategy & & $\mathrm{N}$ & & Mean & Std. Deviation \\
\hline Liquidity requirement & 110 & & 3.81 & & \\
\hline
\end{tabular}

Source: primary data(2021)

Table 4.8 indicated that many respondents are agreeable that liquidity requirement impacts positively the financial performance as it is shown by a high Mean of 3.81 and homogeneous SD as .92 is less than one (SD<1). These findings suggested that the absence or shortage of these loan management strategies should hinder banks' effective financial performance.

The financial performance at Bank of Kigali in Rwanda it is vital to have a pretty good handle on whether one's financial institution is making money and how much it is making. Therefore, Return On Equity and Return On Assets were calculated from the item on the bank of Kigali (as a commercial bank) annual financial statements (i.e., from the year 2016 to 2020). As it has been discussed in the preceding chapter, Return On Equity is calculated as follows:

$$
\mathrm{ROE}=\frac{\text { Net income }}{\text { Average equity }} \times 100
$$

Table:4.4 Return on equity for the years 2016 to 2020

\section{Source: Secondary data (2021)}

Table 4. 9 noted that the bank of Kigali (as a commercial bank) made $91 \%$ in 2016, 94\% in 2017, 95\% in 2018, $94 \%$ in 2019 , and $96 \%$ in 2020 in profit for every \$ 1 invested, respectively. As it has been discussed in the preceding chapter, ROA is calculated as follows:

$$
\mathrm{ROA}=\frac{\text { Net income }}{\text { Average assets }} \times 100
$$

Therefore, by referring to the table 4.11, net income, average assets and ROA for the years from 2016 to 2020 are clarified:

Table: 4.5 Return on assets for the years from 2016 to 2020

\begin{tabular}{llllll}
\hline & Year 2016 & Year 2017 & Year 2018 & Year 2019 & Year 2020 \\
\hline Net income & $14,100,000,000$ & $20,500,000,000$ & $20,800,000,000$ & $23,300,000,000$ & $27,400,000,000$ \\
Average assets & $112,300,000,000$ & $165,000,000,000168,600,000,000$ & $214,000,000,000$ & $248,850,000,000$ \\
ROA & $14,100,000,000$ & $\frac{20,500,000,000}{165,000,000,000}$ & $=\frac{20,800,000,000}{168,600,000,000}$ & $=\frac{23,300,000,000}{214,000,000,000}$ & $=\frac{27,400,000,000}{248,850,000,000}$ \\
& $112,300,000,000$ & $0.12 \times 100=$ & $0.12 \times 100=$ & $0.10 \times 100=10 \%$ & $0.11 \times 100=$ \\
& $=0.12 \times 100$ & $12 \%$ & $12 \%$ & & $11 \%$ \\
& $=12 \%$ & & & & \\
\hline
\end{tabular}

Source: Secondary data (2021)

Referring to table 4.11, it is noted that in the bank of Kigali (as a commercial bank), every $\$ 1$ in assets generated $12 \%, 12 \%, 12 \%, 10 \%$, and $11 \%$ in profits in the years from 2016 to 2020 . Therefore, as this ratio is an economic indicator that is of great importance since it measures the bank's profit for each monetary unit of sale, it is noted that from the year 2016 to 2020, Return On Assets gradually decreased.

The following table 4.12 is about the model summary of the indicators of independent variables (liquidity management requirement and dependent variable (financial performance) 
Table:4.6 Model Summary

\begin{tabular}{lllll}
\hline \multicolumn{2}{l}{ Model Summary } & & \\
\hline Model & $\mathrm{R}$ & R Square & Adjusted R Square & Std. Error of the Estimate \\
1 & $.733^{\mathrm{a}}$ & .543 & .519 & .46753 \\
\hline
\end{tabular}

a. Predictors: (Constant), liquidity management requirement

Source: Primary data(2021)

The table 412 showsAdjusted R squared was 0.519 an indication that there was variation of $51.9 \%$ on financial performance of bank of Kigali, this was because of changes in liquidity requirement ,credit risk management , capital requirement at $95 \%$ confidence interval. Therefore $51.9 \%$ changes in financial performance of bank of Kigali could be accounted for by liquidity management requirement. This indicated that the other variables (factors) that were not studied in this study contributed $48.1 \%$ of the variability on bank of Kigali financial performance. $\mathrm{R}$ is the correlation coefficient that indicates relationship between the studies variables, the findings shows that there was a strong positive relationship between the study variables 0.733 .

Table:4.7 Analysis of variance (ANOVA)

\begin{tabular}{ccccccc}
\hline Model & Sum of Squares & Df & Mean Square & F & Sig. \\
\hline 1 & Regression & 15.386 & 2 & 7.693 & 58.714 & $.000^{\mathrm{a}}$ \\
Residual & 9.169 & 87 & .105 & & \\
Total & 24.555 & 89 & & & \\
\hline
\end{tabular}

a.Predictors: (Constant), liquidity management requirement

b.Dependent Variable: Financial performance

Source: Primary data(2021)

The result showed that overall model was significant at a 95\% confidence level $\mathrm{p}<0.05$ (Sig. $=0.000)$,. This shows that liquidity requirement, credit risk management, capital requirement influence positively financial performance of the bank of Kigali.

Table: 4.8 Regression Coefficients

\begin{tabular}{|c|c|c|c|c|c|c|}
\hline \multirow[b]{2}{*}{ Model } & & \multicolumn{2}{|c|}{$\underline{\text { Unstandardized Coefficients }}$} & \multirow{2}{*}{$\begin{array}{l}\text { Standardized } \\
\text { Coefficients } \\
\text { Beta }\end{array}$} & \multirow[b]{2}{*}{$\mathrm{T}$} & \multirow[b]{2}{*}{ Sig. } \\
\hline & & $\mathrm{B}$ & Std. Error & & & \\
\hline \multirow[t]{2}{*}{1} & (Constant) & .144 & .186 & & 1.851 & .001 \\
\hline & liquidity requirement & .414 & .055 & .225 & 10.046 & .000 \\
\hline
\end{tabular}

a. Dependent Variable: Financial performance

Source: Primary data (2021)

$\boldsymbol{Y}=\boldsymbol{\beta} \mathbf{0}+\boldsymbol{\beta} \mathbf{1} \boldsymbol{X} \mathbf{1}+\epsilon$ Where:

$\boldsymbol{Y}=$ Financial Performance

$\boldsymbol{X} \mathbf{1}=$ liquidity requirement

$\boldsymbol{\beta 0}=$ the constant

$\epsilon=$ error term

As per the SPSS results generated, the equation translates to: Financial performance $=0.144+0.454 X 1$

Where; financial performance $=$ Constant + liquidity management requirement.

The results in Table 4.14 denote that liquidity management requirement relates positively with the financial performance of bank of Kigali, and the relationship is significant since ( $\beta$ eta $=0.225$, Sig <0.5; Sig $=0.000)$. These findings indicate that loan management strategies have a significant impact on any bank's financial performance; it means that when there are reasonable loan management strategies in the bank, the profitability is also good, but if loan management strategies are poor, the profitability is low. The profitability, in this case, depends on loan management strategies the findings concur with that of Felix and Claudine (2011)

\subsection{Summary, Conclusions And Recommendations \\ 5.1Summary}

On the sampled bank of Kigali branches that Liquidity management affects financial performance of our bank by a high mean of 3.98 and homogeneous perception as the standard deviation was 0.92 . The findings suggested that the more than $70 \%$ of respondents confirmed that liquidity requirement was used as the critical measure of prudential loan management to ensure banks' financial performance. of prudential loan management strategies has a significant positive association with the performance of a bank of Kigali as it is being indicated by the views of liquidity 
management requirement relates positively with financial performance of bank of Kigali and the relationship is significant since $(\beta=0.225, \mathrm{p}<0.5 ; \mathrm{p}=0.000)$

\subsection{Conclusion}

In conclusion, therefore, for objective one, the study results indicated that prudential credit risk management strategies, were at a suitable level, as noted in the findings. However, there is room for upgrading to reach the maximum profit. For objective two, Kigali's bank has improved well due to prudential loan management tools utilized from 2016 to 2020 .

\section{ACKNOWLEDGEMENT}

I acknowledge God because of providing forte, audacity as well as good well-being during period of this compiling the project. Subsequent, I appreciate Dr. Safari Ernest and Dr Paul Munene for their guidance as my supervisors. I also thank Bank of Kigali for the cooperation during the study especially during data collection which made this project report a success

Thirdly mother Nyiramasasu Marie, brothers Frank and Josue and sisters Sifa, Furaha and Gabriella for everything they have done for me during my studies, I can't get words to express how I am grateful and blessed to have them. Another greatest thankful goes to Muhimpundu Colette for her constant encouragement, inspiration and support exhibited throughout my courses.

\section{References}

[1].Ali, A.E.E.S. (2015). The Regulatory and Supervision Framework of Microfinance in Kenya.International Journal of Social Science Studies, 3(5), 123-130

[2].Loutskina, E., \& Strahan, P. E. (2018). Informed and uninformed investment in housing: The downside of diversification. The Review of Financial Studies, 24(5), 1447-1480.

[3].Odunga, R. M., Nyangweso, P. M., Carter, D. A., \& Mwarumba, M. (2013). Credit Risk, “Capital Adequacy and Operating Efficiency Of Commercial Banks in Kenya”. International Journal of Business and Management Invention, 2(9), 6-12.

[4].Kamau, A. W. (2009). Efficiency in the banking sector: An empirical investigation of commercial banks in Kenya Unpublished PhD dissertation University of Nairobi

[5].Amin, M. (2015).Social science research: conception, methodology and analysis. Kampala Uganda: Makerere University Fredrick, O. (2012). The Impact of Credit Risk Management on Financial Performance of Commercial Banks in Kenya.

[6].DBA Africa Management Review, 3(1): 22-37

[7].Paul .(2015). Effects of Central bank regulatory requirements on financial performance of commercial banks in Kenya.Unpublished PhD Thesis in finance, Jomo Kenyatta University of Agriculture and Technology, Kenya

[8].MWINE, J. (2018). "Non-performing loans and banks financial performance in Rwanda": a case study of selected commercial banks in Rwanda. A Master's thesis, Mount Kenya University.

[9].Pandlev, S. (2010). “The causes of banks failures". In MullineuxA W, Murinde V. handbook of international banking.

[10]. Edward Elgar. 366-402

[11]. Richard E. (2011). Factors That Cause Non- Performing Loans in Commercial Banks in Tanzania and Strategies to Resolve Them.Journal of Management Policy and Practice 12(7).

[12]. Tang, N.J. (2003). The profitability of banking sector in Hong Kong.In Hong Kong Monetary Authority Quarterly Bulletin.pp. 5- 14 . 